\title{
INTERNATIONAL COMMISSION ON LARGE DAMS
}

COMMISSION INTERNATIONALE DES GRANDS BARRAGES

GENERAL ARRANGEMENT

ORGANISATION GENERALE

2019 ANNUAL MEETING, OTTAWA

Canada, 9 - 14 June 2019

REUNION ANNUELLE 2019, OTTAWA

Canada, 9 - 14 juin 2019

GENERAL ASSEMBLY $\left(87^{\text {th }}\right)$

AGENDA

ASSEMBLÉE GÉNÉRALE (87 $\left.{ }^{\text {ème }}\right)$

ORDRE DU JOUR 


\section{A) GENERAL ARRANGEMENTS}

\section{1/ VENUE OF THE MEETINGS}

All the meetings (Annual Meeting, Symposium and Workshops) will be held in the Shaw Centre, from 9 to 14 June 2019.

\section{2/ TIME-SCHEDULE OF THE MEETINGS}

\section{Saturday, 8 June}

Board Meeting

\section{Sunday, 9 June}

- Board Meeting

- Board \& Organizing Committee Meeting

- Board \& Technical Committees Chairmen Meeting

\section{Monday, 10 June}

- Board Meeting

- Meetings of Regional Clubs

- Technical Workshops

\section{Tuesday, 11 June}

- Technical Committee Meetings

\section{Wednesday, 12 June}

- International Symposium

\section{Thursday, 13 June}

- Technical Tours

- International Symposium

\section{A) ORGANISATION GÉNÉRALE}

\section{1/ LIEU DES RÉUNIONS}

Toutes les réunions (Réunion Annuelle, Symposium et Ateliers) se tiendront au Centre Shaw, du 9 au 14 juin 2019.

\section{2/ HORAIRES DES RÉUNIONS}

\section{Samedi 8 juin}

Réunion du Conseil d'Administration

\section{Dimanche 9 juin}

- Réunion du Conseil d'Administration

- Réunion du Conseil d'Administration \& du Comité d'Organisation

- Réunion du Conseil d'Administration \& des Pts des Comités Tech.

\section{Lundi 10 juin}

- Réunion du Conseil d'Administration

- Réunions des Clubs Régionaux

- Ateliers Techniques

\section{Mardi 11 juin}

- Réunions des Comités Techniques

\section{Mercredi 12 juin}

- Symposium International

\section{Jeudi 13 juin}

- Visites techniques

- Symposium International 
The ICOLD Technical Committees are expected to meet during the Annual Meeting, as follows:
Les Comités Techniques de la CIGB se réuniront durant la Réunion

Annuelle comme suit :

\section{ICOLD TECHNICAL COMMITTEES / COMITÉS TECHNIQUES DE LA CIGB}

\author{
COMPUTATIONAL ASPECTS OF ANALYSIS \& DESIGN OF DAMS \\ SEISMIC ASPECTS OF DAM DESIGN \\ HYDRAULICS FOR DAMS \\ CONCRETE DAMS \\ EMBANKMENT DAMS \\ ENGINEERING ACTIVITIES WITH THE PLANNING PROCESS FOR WATER \\ RESOURCES PROJECTS \\ ENVIRONMENT \\ DAMS SAFETY \\ PUBLIC SAFETY AROUND DAMS \\ SEDIMENTATION OF RESERVOIRS \\ INTEGRATED OPERATION OF HYDROPOWER STATIONS AND \\ RESERVOIRS \\ TAILINGS DAMS \& WASTE LAGOONS \\ LEVEES \\ OPERATION, MAINTENANCE AND REHABILITATION OF DAMS \\ PUBLIC AWARENESS AND EDUCATION \\ WORLD REGISTER OF DAMS AND DOCUMENTATION \\ CEMENTED MATERIAL DAMS \\ DAMS SURVEILLANCE \\ RESETTLEMENT DUE TO RESERVOIRS \\ FLOODS EVALUATION AND DAMS SAFETY \\ PROSPECTIVE AND NEW CHALLENGES FOR DAMS AND RESERVOIRS \\ IN THE 21st CENTURY \\ DAMS AND RIVERS BASIN MANAGEMENT \\ HYDROMECHANICAL EQUIPMENTS \\ SELECTION OF DAM TYPE \\ CLIMATE CHANGE \\ CAPACITY BUILDING AND DAMS
}

Please note: All reports of the Committees must be delivered to the Secretariat (better by e-mail nathalie.schauner@icold-cigb.org) as soon as possible for reproduction so that distribution to the delegates can be effected during the General Assembly.

Former Chairmen of Technical Committees are invited to attend their former Technical Committee. The same applies for Past ICOLD

Presidents and Vice Presidents for any ICOLD Committee Meeting.

List of Technical Committees, Technical Committee Chairmen and names of Technical Committee members are available on the ICOLD website under the folder Member Section and then Directory (www.icold-cigb.net).

Please advise Central Office of any errors or omissions.
METHODES DE CALCULS POUR BARRAGES

ASPECTS SISMIQUES DES PROJETS DE BARRAGES

HYDRAULIQUE DES BARRAGES

BARRAGES EN BETON

BARRAGES EN REMBLAI

ACTIVITÉS D'INGÉNIERIE DANS LE PROCESSUS DE PLANIFICATION 2014-17

DES PROJETS DE RESSOURCES EN EAU

ENVIRONNEMENT

SECURITE DES BARRAGES

SÉCURITÉ DU PUBLIC PRÈS DES BARRAGES

ALLUVIONNEMENT DES RETENUES

EXPLOITATION INTÉGRÉE DES CENTRALES

HYDROÉLECTRIQUES ET DES RÉSERVOIRS

BARRAGES ET DEPOTS DE STERILES

LES DIGUES

EXPLOITATION, ENTRETIEN ET REHAB. DES BAR.

INFORMATION DU PUBLIC ET ÉDUCATION

REGISTRE MONDIAL DES BARRAGES ET DE LA DOC.

BARRAGES EN REMBLAI CIMENTE

SURVEILLANCE DES BARRAGES

REINSTALLATION DUE AUX RESERVOIRS

ESTIMATION DES CRUES ET SECURITE DES BARRAGES

PERSPECTIVES ET NOUVEAUX DÉFIS DES BARRAGES ET

RESERVOIRS AU XXI ${ }^{\circ}$ SIECLE

GESTION DES BARRAGES ET DES BASSINS FLUV.

ÉOUIPEMENTS HYDROMÉCANIQUES

CHOIX DU TYPE DE BARRAGE

CHANGEMENT CLIMATIQUE

RENFORCEMENT DES MOYENS PROPRES

2017-20

2018-21

2016-19

$2017-20$

2015-19

2017-20

2018-21

2017-20

2018-21

$2017-20$

2017-20

2017-20

2018-21

2015-20

2017-20

2018-21

2016-19

2015-18

2017-21

2017-21

Veuillez bien noter que tous les rapports doivent être remis au Secrétariat (de préférence par e-mail à nathalie.schauner@icold-cigb.org) aussitôt que possible pour être reproduits, afin qu'ils soient remis aux délégués pendant l'Assemblée Générale.

Les anciens Présidents des Comités Techniques sont invités à prendre part aux réunions de leurs anciens Comités Techniques. Il en est de même pour les anciens Présidents et Vice-Présidents de la CIGB pour n'importe quelle réunion de Comités de la CIGB.

La liste des Comités Techniques, de leurs Présidents et les noms des membres des Comités Techniques sont disponibles sur le site de la CIGB au chapitre Section Membres puis Annuaire (www.icold-cigb.net).

SVP Veuillez bien aviser le Bureau Central de toute erreur ou omission. 


\section{Friday, 14 June}

- $87^{\text {th }}$ General Assembly

- Technical Workshops

\section{3/ APPOINTMENT OF REPRESENTATIVES OF NATIONAL COMMITTEES AT THE $87^{\text {th }}$ GENERAL ASSEMBLY}

"Each National Committee shall notify the Secretary General of the name of its member with voting power and also the names of other representatives who will be present as delegates at the General Assembly" (Constitution VI, 7).

\section{4/ SUBMISSION OF ADDITIONAL ITEMS FOR THE AGENDA OF} GENERAL ASSEMBLY (Constitution VI, 5)

"Any matter not on the Agenda which a National Committee desires to raise at a General Assembly must be submitted in writing to the Secretary General and received by him/her not less than two weeks before the-date of the General Assembly, otherwise it shall not be considered" (Constitution VI, 5). See also Circular Letter 1922 of 31 July 2017 "List of Important Dates".

\section{B) AGENDA OF THE $87^{\text {th }}$ GENERAL ASSEMBLY}

\section{CALL OF THE MEETING TO ORDER BY THE PRESIDENT}

\section{OBITUARY}

A minute of silence will be observed.

\section{Vendredi 14 juin}

- $87^{\text {ème }}$ Assemblée Générale

- Ateliers Techniques

\section{3/ DÉSIGNATION DES REPRÉSENTANTS DES COMITÉS NATIONAUX} À LA $87^{\text {ème }}$ ASSEMBLÉE GÉNÉRALE

«...chaque Comité National devra notifier au Secrétaire Général le nom de celui de ses membres désigné comme délégué officiel, ainsi que les noms des autres représentants qui assisteront comme délégués à l'Assemblée Générale »(Statuts VI, 7).

\section{4/ INSCRIPTION DE QUESTIONS SUPPLÉMENTAIRES À L'ORDRE DU} JOUR DE I'ASSEMBLEE GÉNÉRALE (Statuts VI, 5)

«Toute question ne figurant pas à l'Ordre du Jour, mais qu'un Comité National désire soulever lors de l'Assemblée Générale, doit être soumise par écrit au Secrétaire Général et reçue par lui au plus tard deux semaines avant la date de l'Assemblée Générale, faute de quoi cette question ne serait pas prise en considération » (Statuts VI, 5). Voir aussi Circulaire 1922 du 31 juillet 2017 « Liste des dates importantes ».

B) ORDRE DU JOUR DE LA $87^{\text {ème }}$ ASSEMBLÉE GÉNÉRALE

\section{LE PRESIDENT DECLARE LA SEANCE OUVERTE.}

\section{NÉCROLOGIE}

Une minute de silence sera observée. 


\section{1.- EXPLANATION FOR COUNT OF VOTES [By-Laws C(2)]}

Vote count, if necessary, will be made by a clerk from Central Office in the presence of Vice-Presidents Michael Abebe (Ethiopia) and Ali Noorzad (Iran)

\section{2.- ADOPTION OF THE PROPOSED AGENDA}

The President shall call for a vote of hands for approval of the agenda.

\section{3.- APPROVAL OF THE MINUTES OF THE $86^{\text {th }}$ GENERAL ASSEMBLY}

The Minutes were sent to all National Committees under cover of Circular Letter No. 1938 of 21 August 2018.

Requests for corrections have been received (in bold):

- Extend the term for 3 years of the Committee $\mathbf{M}$ - Operation, Maintenance and Rehabilitation of dams (2017-2020)

3BIS. - FILM ON THE HIGHLIGHTS OF ICOLD ACTIVITIES SINCE LAST GENERAL ASSEMBLY.

\section{4.- PRESIDENT'S ADDRESS ON BOARD ACTIONS}

The President Michael Rogers will present the actions he initiated and entrusted to the Board members.

\section{1.- EXPLICATION POUR LE DÉPOUILLEMENT DES SCRUTINS [Règlt. Int. C(2)]}

II sera effectué, s'il y a lieu, par un employé du Bureau Central, en présence des Vice-Présidents Michael Abebe (Éthiopie) et Ali Noorzad (Iran).

\section{2.- APPROBATION DE L'ORDRE DU JOUR}

Le Président fera un vote à mains levées pour l'approbation de l'Agenda.

\section{3.- APPROBATION DU PROCÈS-VERBAL DE LA 86 ${ }^{\text {ème }}$ ASSEMBLÉE GÉNÉRALE}

Le Procès-Verbal a été envoyé à tous les Comités Nationaux par Circulaire $\mathrm{n}^{\circ} 1938$ du 21 aout 2018.

Des demandes de correction ont été formulées (en gras) :

- Prolongation de 3 ans du mandat du Comité $\mathbf{M}$ - Exploitation, Entretien et Exploitation des Barrages (2017-2020)

3BIS. - FILM SUR LES ACTIVITES DE LA CIGB PASSEES DEPUIS LA DERNIERE ASSEMBLEE GENERALE.

\section{4.- DISCOURS DU PRÉSIDENT SUR LES ACTIONS DU CONSEIL D'ADMINISTRATION}

Le Président Michael Rogers présentera les actions qu'il a initiées et confiées aux membres du Conseil d'Administration. 


\section{5.- CHOICE OF TECHNICAL QUESTIONS FOR THE $27^{\text {th }}$ CONGRESS (By-Laws, Section $\mathrm{J}$ - $\mathrm{b}$ to $\mathrm{f}$ )}

A discussion and election of the 4 questions for the $27^{\text {th }}$ Congress (Marseille, France 2021) will be made according to the procedure of the By-Laws.

i) President's question. It will be subjected to a ballot and, if approved, will be the first Question on the final list.

ii) Discussion of the list of the 7 proposals of Questions prepared by the Secretary General (Annex 3).

iii) Selection of the Questions by voting.

iv) The President will name the members of the Special Committee who shall meet forthwith to prepare the explanatory notes of the Questions which will be submitted to the General Assembly at the end of the meeting. The Special Committee shall be dismissed for their work immediately after.

NOTE: The deadline for receiving Congress question proposals at the Central Office was 13 February 2019.

\section{6.- INFORMATION ON ICOLD MEMBERSHIP}

\subsection{New application for membership (Constitution III, 1)}

The Secretary General will review the position of the countries that have shown interest in joining ICOLD.

By letter dated $1^{\text {st }}$ August 2018, Central Office had received a formal application for membership from Uganda. The Secretary General is satisfied that this application is in order » and the 87th General Assembly will be invited to formally elect Uganda as the 101th ICOLD member. (Annex 4).

\section{5.- CHOIX DES QUESTIONS TECHNIQUES POUR LE 27 ${ }^{\text {ème }}$ CONGRÈS (Règlement Intérieur, Article $\mathrm{J}$ - b à f)}

Une discussion suivie d'un choix des 4 questions pour le $27^{\text {ème }}$ Congrès (Marseille, France 2021) se fera conformément à la procédure du Règlement Intérieur

i) Question du Président. Elle sera soumise à vote et, si elle est retenue, constituera la première Question de la liste définitive.

ii) Discussion de la liste des 7 propositions de Questions préparées par le Secrétaire Général (annexe 3).

iii) Choix des Questions par vote.

iv) Le Président annoncera la composition du Comité Spécial qui se réunira pour préparer les notes explicatives des Questions qui seront soumises à l'Assemblée Générale en fin de réunion. Le Comité Spécial sera dissout immédiatement après.

NOTE : La date limite de réception des propositions des questions du Congrès au Bureau Central était le 13 février 2019.

\section{6.- INFORMATION SUR LES PAYS MEMBRES DE LA CIGB}

\subsection{Nouvelle adhésion (Statuts III, 1)}

Le Secrétaire Général fera le point sur les pays qui ont montré leur intérêt à rejoindre la CIGB.

Le Bureau Central a reçu, par lettre du $1^{\text {er }}$ aout 2018, une demande formelle d'adhésion de l'Ouganda. Le Secrétaire Général estime que cette demande est recevable et la 87ème Assemblée Générale sera invitée à procéder à l'élection de l'Ouganda comme 101ème membre de la CIGB. (Annexe 4) 


\subsection{Exclusion of member countries (By-Laws $U, a)$}

The Secretary General will review the position.

\section{7.- ELECTIONS (Term of office 2018 - 2021)}

\section{1.- Election of Vice-Presidents (By-Laws, Section E)}

\subsection{1.- Posts to be filled this year.}

Two posts are to be filled (term of office 2019-2022):

a) One nomination for the European Zone. Post to succeed to Michel Lino (France), whose term of office will expire in 2019. Nominations should come only from the European Zone.

Central Office has received the nomination of:

1) Enrique Cifres (Spain) (Annex 5)

b) One nomination to the $6^{\text {th }}$ Post to succeed to J. Zhou (China), whose term of office will expire in 2019. Nomination should come from all zones except the Europe zone.

Central Office has received nominations of:

1) Tetsuya Sumi (Japan) (Annex 6)

2) Prof. Ashraf El-Ashaal (Egypt) (Annex 7)

3) Devendra K Sharma (India) (Annex 9)

NOTE: The final date for receiving nominations for Vice President was 14 March 2019.

\subsection{Exclusion de pays membres (Règlt. Int. $U, a)$.}

Le Secrétaire Général fera le point.

\section{7.- ÉLECTIONS (Mandat 2018 - 2021)}

\section{1.- Élection des Vice-Présidents (Règlt. Intérieur, Article E)}

\subsection{1.- Postes à pourvoir cette année.}

Deux postes sont à pourvoir (mandat 2019-2022) :

a) Un poste pour la Zone Europe, pour succéder à Michel Lino (France), dont le mandat viendra à expiration en 2019. Les candidats doivent provenir seulement de la Zone Europe.

Le Bureau Central a reçu la candidature de :

1) Enrique Cifres (Espagne) (Annexe 5)

b) Un 6ème poste pour succéder à J. Zhou (Chine), dont le mandat viendra à expiration en 2019. Les candidats doivent provenir de toutes les zones, exceptée de la zone Europe.

Le Bureau Central a reçu les candidatures de :

1) Tetsuya Sumi (Japon) (Annexe 6)

2) Prof. Ashraf El-Ashaal (Egypte) (Annexe 7)

3) Devendra K Sharma (Inde) (Annexe 9)

NOTE : La date limite de réception des candidatures pour les postes de Vice-Présidents était le 14 mars 2019. 
7.1.2.- Posts to be filled next year (2020) - [By-Laws E (e)]

The Secretary General will state the geographical locations for the two Vice-Presidents to be elected at the General Assembly of New-Delhi (India) in 2020.

See in Annex 1 the geographical distribution of the posts of VicePresidents and in Annex 2 the list of ICOLD Officers as from 1973.

\section{8.- FINANCIAL STATEMENTS}

8.1. Financial Statements for the past year (2018)

\subsection{Budget for the next year (2020)}

Secretary General and Auditor's Reports are given in Annexes 8.

Operating Account, Balance Sheet for 2018 and Budget for 2020 appear in Annexes. Comments from the Financial and Advisory Committee will be made at the session.

\section{9.- REPORT ON ARRANGEMENTS FOR THE $88^{\text {th }}$ ANNUAL MEETING IN 2020, (India).}

A report will be presented by the official delegate of the Indian Committee.

\section{0.- REPORT ON ARRANGEMENTS FOR THE $89^{\text {th }}$ ANNUAL MEETING \& $27^{\text {th }}$ CONGRESS IN 2021, Marseilles (France).}

A report will be presented by the official delegate of the French Committee.

\section{1.- REPORT ON ARRANGEMENTS FOR THE $90^{\text {th }}$ ANNUAL} MEETING in 2022, Shiraz (Iran).

A report will be presented by the official delegate of the Iranian National Committee on Large Dams
7.1.2.- Postes à pourvoir l'an prochain (2020) - [Règlt. Intérieur E (e)]

Le Secrétaire Général indiquera les zones géographiques des deux VicePrésidents à élire à l'Assemblée Générale de New-Delhi (Inde) en 2020.

Ci-joint en Annexe 1 la répartition géographique des postes de VicePrésidents et en Annexe 2 la liste des Membres du Bureau depuis 1973.

\section{8.- EXPOSÉS FINANCIERS}

8.1. Comptes pour l'année écoulée (2018)

\subsection{Budget pour l'année prochaine (2020)}

Les Rapports du Secrétaire Général et du Commissaire aux Comptes sont donnés en Annexes 8.

Le Compte d'Exploitation, le Bilan pour 2018 et le Budget 2020 sont donnés dans les Annexes. L'avis du Comité Finances et Conseils sera donné en séance.

\section{9.- RAPPORT SUR L'ORGANISATION DE LA $88^{\text {ème }}$ RÉUNION ANNUELLE EN 2020, (Inde).}

Un rapport sera présenté par le délégué officiel du Comité Indien.

10.- RAPPORT SUR L'ORGANISATION DE LA 89 ème RÉUNION ANNUELLE \& LE $27^{\text {ème }}$ CONGRES EN 2021, Marseille (France).

Un rapport sera présenté par le délégué officiel du Comité Français.

11.- RAPPORT SUR L'ORGANISATION DE LA 90ème RÉUNION ANNUELLE EN 2022, Chiraz (Iran).

Un rapport sera présenté par le délégué officiel du Comité National Iranien des Grands Barrages. 
12.- INVITATIONS TO HOST THE 91 ${ }^{\text {st }}$ ANNUAL MEETING IN 2023.

By letter dated 7 March 2019, Central Office received for an invitation to host the $91^{\text {st }}$ Annual Meeting in 2023 (Annex 10) from:

1) ICOLD SWEDISH NATIONAL COMMITTEE, SWEDCOLD

NOTE: The final date for receiving invitations was 14 March 2019.

This invitation will be discussed and put to the vote.

\section{3.- TECHNICAL OR OTHER MATTERS RAISED BY NATIONAL COMMITTEES (Constitution VI; 3)}

The President will review the positions, as necessary.

\section{4.- PRESIDENT'S PROPOSALS}

\subsection{Setting up of new Technical Committees}

The President will review the positions, as necessary.

\subsection{Re-appointment or extension of the term of office of} Technical Committees

- Extend the term and update the mandate of Committee F Engineering Activities with the Planning Process for Water Resources Projects (2019-2022) (Annex 11)

- Extend the term and update the mandate of Committee $\mathrm{K}$ Integrated Operation Of Hydropower Stations And Reservoirs (2020-2023) (Annex 12)

- Extend the term and update the mandate of Committee $\mathrm{V}$ Hydromechanical Equipment (2019-2022) (Annex 13)
12.- INVITATIONS POUR ACCUEILLIR LA $91^{\text {ème }}$ RÉUNION ANNUELLE EN 2023.

Le Bureau Central a reçu, par lettre du 7 mars 2019, une invitation pour accueillir la 91 ${ }^{\text {ème }}$ Réunion Annuelle en 2023 (Annexe 10) du :

1) COMITÉ NATIONAL SUEDOIS de la CIGB, SWEDCOLD

NOTE : La date limite de réception des invitations était le 14 mars 2019.

Cette invitation sera discutée et soumise au vote.

\section{3.- QUESTIONS TECHNIQUES OU AUTRES SOULEVÉES PAR LES COMITÉS NATIONAUX (Statuts VI, 3)}

Le Président passera en revue les postes, si nécessaire.

\section{4.- PROPOSITIONS DU PRÉSIDENT}

\subsection{Création de nouveaux Comités Techniques}

Le Président passera en revue les postes, si nécessaire.

\subsection{Renouvellement ou prolongation du mandat des Comités} Techniques

- Prolongation et mise à jour du mandat du Comité F - Activités d'Ingénierie dans le Processus de Planification des Projets de Ressources en Eau (2019-2022) (Annexe 11)

- Prolongation et mise à jour du mandat du Comité $\mathrm{K}$ - Exploitation Intégrée Des Centrales Hydroélectriques Et Des Réservoirs (20202023) (Annexe 12)

- Prolongation et mise à jour du mandat du Comité V - Les Equipements Hydromécaniques (2019-2022) (Annexe 13) 


\subsection{New Chairmen and/or Members of Technical Committees}

A - Computational Aspects of Analysis and Design of Dams:

- Phoebe Percell (USA) to take over from Enrique Matheu (USA)

- Yi Liu (China) to take over from Shenghong Chen (China)

- Mariyathas Ajanthiny (Sri Lanka)

- Graham Roberts (South Africa)

- Xavier Molin (France) to take over from Etienne Frossard (France)

- Eugeniy Vitokhin (Russia) (Co-opted Member)

- Ehab A. Khalil (Egypt)

- Mateja Klun (Slovenia) instead of M. Klun (Slovenia)

B - Seismic Aspects of Dam Design:

- Bandula Kendaragama (Sri Lanka)

- Rajeev Kumar Vishnoi (India) to take over from A.B. Pandya (India)

C - Hydraulics for Dams:

- Arthur Yapa (Sri Lanka)

D - Concrete Dams:

- Bård Arntsen (Norway)

- Pedro Ferreira da Silva (Portugal) as co-opted member

\section{E - Embankment Dams:}

- Fuqiang Wang (China)

\section{F - Engineering Activities with the Planning Process for Water} Resources Projects:

- Hama Ould Sidi Mohamed, ARBI (Mali) as Chairman

\section{G - Environment:}

- Yuta Fukuda (Japan) co-opted member.

- M. Muschett (Panama)

- Goro Yasuda (Japan), to take over from Tadashi Kitamura (Japan)

\subsection{Nouveaux Présidents et/ou Membres de Comités Techniques}

\section{A - Méthodes de Calculs pour Barrages}

- Phoebe Percell (USA) en remplacement de Enrique Matheu (USA)

- Yi Liu (Chine) en remplacement de Shenghong Chen (Chine)

- Mariyathas Ajanthiny (Sri Lanka)

- Graham Roberts (Afrique du Sud)

- Xavier Molin (France) en remplacement de Etienne Frossard (France)

- Euneniy Vitokhin (Russie) (Membre Co-opté)

- Ehab A. Khalil (Egypte)

- Mateja Klun (Slovenie) à la place de M. Klun (Slovenie)

B - Aspects Sismiques des Projets de Barrages :

- Bandula Kendaragama (Sri Lanka)

- Rajeev Kumar Vishnoi (Inde) en remplacement de A.B. Pandya (Inde)

\section{C - Hydraulique des Barrages :}

- Arthur Yapa (Sri Lanka)

D - Barrages en Béton :

- Bård Arntsen (Norvège)

- Pedro Ferreira da Silva (Portugal) comme membre co-opté

\section{E - Barrages en remblais :}

- Fuqiang Wang (Chine)

F - Activités d'Ingénierie dans le Processus de Planification des Projets de Ressources en Eau :

- Hama Ould Sidi Mohamed, ARBI (Mali), comme Président

\section{G -Environnement :}

- Yuta Fukuda (Japon) membre coopté.

- M. Muschett (Panama)

- Goro Yasuda (Japon), en remplacement de Tadashi Kitamura (Japon) 


\section{H - Dam Safety:}

- Marc Balissat (Switzerland), Vice-Chairman, to take over from Gus Tjoumas (USA).

I - Public Safety Around Dams:

- Ms Z Mathe, remove (South Africa)

\section{J - Sedimentation of Reservoirs:}

- Dr. Kees Sloff (Netherlands)

- Ahmed F. Chraibi (Morocco)

K - Integrated Operation of Hydropower Stations and Reservoirs:

L - Tailings Dams and Waste Lagoons:

- Jiří Herza (Czech Republic)

\section{LE - Levees}

M - Operation, Maintenance and Rehabilitation of dams:

- Sudharshanie Widanapathirana (Sri Lanka)

- Shri Dhirendra Veer Singh (India) to take over from Mr Vhisnoi (India)

N - Public Awareness and Education:

O - World Register of Dams and Documentation:

- Masayuki Kashiwayanagi (Japan), to take over from Norihisa Matsumoto (Japan)

P - Cemented Material Dams:

- M.D.J.P. Wickramasooriya (Sri Lanka)

Q - Dam Surveillance:

- Mr. Juan Mata (Portugal) as co-opted member
H - Sécurité des Barrages :

- Marc Balissat (Suisse), Vice-Président, en remplacement de Gus Tjoumas (USA).

I - Sécurité du Public près des Barrages :

- Ms Z Mathe, départ (Afrique du Sud)

J - Alluvionnement des Retenues :

- Dr. Kees Sloff (Pays-Bas)

- Ahmed F. Chraibi (Maroc)

K - Exploitation intégrée des Centrales Hydroélectriques et des Réservoirs :

L - Barrages et Dépôts de Stériles :

- Jiří Herza (Rép. Tchèque)

\section{LE - Digues}

M - Exploitation, Entretien et Réhabilitation des Barrages :

- Sudharshanie Widanapathirana (Sri Lanka)

- Shri Dhirendra Veer Singh (Inde) en remplacement de M. Vhisnoi (Inde)

N - Information et Éducation du Public :

O - Registre Mondial des Barrages et de la Documentation :

- Masayuki Kashiwayanagi (Japon), en remplacement de Norihisa Matsumoto (Japon)

P - Barrages en Remblai Cimenté :

- M.D.J.P. Wickramasooriya (Sri Lanka)

Q - Surveillance des Barrages :

- Mr. Juan Mata (Portugal) comme membre co-opté 
RE - Resettlement due to Reservoirs

- Ms. Kogi Naidoo (South Africa)

- Koji Tabata (Japan), to take over from Shigeru Ariga (Japan)

- Ricardo Alberto Cazeuneve (Argentina)

\section{S - Flood Evaluation and Dam Safety:}

T - Prospective and New Challenges for Dams and Reservoir in the 21st Century:

- Guanfu Chen (China)

- Philippe Lazaro (Switzerland)

- Adrian Morales (Spain)

\section{U - Dams and River Basin Management:}

- Gerald de Jager (South Africa)

V - Hydromechanical Equipment:

- Rudolf van Wyk (South Africa)

- Kaivan Kavianpour (Iran)

W - Selection of Dam Type:

Y - Climate Change:

- Tarun Agarwal (India)

\section{Z - Capacity building and Dams:}

- Vicci Schoeman (South Africa)
RE - Réinstallation due aux Réservoirs

- Ms. Kogi Naidoo (Afrique du Sud)

- Koji Tabata (Japon), en remplacement de Shigeru Ariga (Japon)

- Ricardo Alberto Cazeuneve (Argentine)

\section{S - Estimation des Crues et Sécurité des Barrages :}

$\mathrm{T}$ - Les perspectives et les nouveaux défis des barrages et reservoirs au 21ème Siècle :

- Guanfu Chen (Chine)

- Philippe Lazaro (Suisse)

- Adrian Morales (Espagne)

U - Gestion des Barrages et des Bassins fluviaux :

- Gerald de Jager (Afrique du Sud)

V - Équipement Hydromécaniques :

- Rudolf van Wyk (Afrique du Sud)

- Kaivan Kavianpour (Iran)

W - Choix du Type de Barrage :

Y - Changement Climatique :

- Tarun Agarwal (Inde)

Z - Renforcement des moyens propres :

- Vicci Schoeman (Afrique du Sud) 


\section{5.- INFORMATIONS}

\section{1.- Technical Committees}

\section{2.- European Project}

15.3.- Young Engineers Forum

15.4.- Regional Clubs

15.5.- World Register of Dams

15.6.- International Publisher for ICOLD Publications

\section{7.- Website}

15.8.- Newsletter

\section{9.- Others}

\section{6.- REPORTS SUBMITTED BY TECHNICAL COMMITTEES SINCE} THE LAST GENERAL ASSEMBLY

Six reports have been received for discussion at the meeting:

\section{5.- INFORMATIONS}

\section{1.- Comités Techniques}

15.2.- Projet Européen

15.3.- Forum des Jeunes Ingénieurs

\section{4.- Clubs Régionaux}

15.5.- Registre Mondial des Barrages

15.6.- Éditeur International pour les publications de la CIGB

15.7.- Site web

\section{8.- Newsletter}

\section{9.- Autres}

\section{6.- RAPPORTS PRÉSENTÉS PAR LES COMITÉS TECHNIQUES DEPUIS LA DERNIÈRE ASSEMBLÉE GÉNÉRALE}

Six rapports ont été reçu pour être discutés en réunion :

1) Tailings Dams Design - Technology Update

submitted by the Committee on Tailings Dams \& Waste Lagoons, available on the ICOLD web site, Circular Letter 1940 of 22 October 2018. présenté par le Comité sur les Barrages et Dépôts de Stériles, disponible sur le site Internet de la CIGB, Circulaire 1940 du 22 octobre 2018.

\section{2) Geotextile Filters in Dams}

submitted by the Committee on Embankment Dams, available on the ICOLD web site, Circular Letter 1943 of 14 February 2019.

présenté par le Comité sur les Barrages en remblai, disponible sur le site Internet de la CIGB, Circulaire 1943 du 14 février 2019.

3) Sediment management in reservoirs : National Regulations and Case Studies 


\section{4) Selection of Dam Type}

submitted by the Committee On Selection Of Dam Type, available on the ICOLD web site, Circular Letter 1949 of 10 March 2019. présenté par le Comité sur le Choix Du Type De Barrage, disponible sur le site Internet de la CIGB, Circulaire 1949 du 10 mars 2019.

5) Management Of Expansive Chemical Reactions In Concrete Dams \& Hydroelectric Projects

submitted by the Committee On Concrete Dams, available on the ICOLD web site, Circular Letter 1950 of 28 March 2019. présenté par le Comité sur les Barrages en Béton, disponible sur le site Internet de la CIGB, Circulaire 1950 du 28 mars 2019.

\section{6) Challenges And Needs For Dams In The 21st Century}

submitted by the Committee on Emerging Challenges and Solutions, available on the ICOLD web site, Circular Letter 1951 of 12 April 2019.

Final date for receiving reports at Central Office was 14 March 2019.

\section{7.- TECHNICAL COMMITTEES PROGRESS REPORTS}

The Progress Reports will be distributed during the General Assembly. Some Committees will be called upon to present their report orally at the General Assembly.

Please note: All reports of the Committees must be delivered to the Secretariat (better by e-mail nathalie.schauner@icold-cigb.org) as soon as possible for reproduction so that distribution to the delegates can be effected during the General Assembly.

\section{8. - FINAL WORDING OF THE FOUR QUESTIONS FOR THE $27^{\text {TH }}$ CONGRESS (By-Laws, J-f)}

After discussion of the explanatory notes to the Questions put forward by the ad hoc Committee, the final wording of each Question shall be put separately to a show of hands présenté par le Comite Des Nouveaux Défis Et Solutions, disponible sur le site Internet de la CIGB, Circulaire 1951 du 12 avril 2019.

La date limite de réception des rapports au Bureau Central était le 14 mars 2019.

\section{7.- RAPPORTS D'ACTIVITÉ DES COMITÉS TECHNIQUES}

Les rapports d'avancement seront distribués pendant l'Assemblée Générale. Quelques Comités seront appelés à présenter oralement leur rapport à l'Assemblée Générale.

Veuillez bien noter que tous les rapports doivent être remis au Secrétariat (de préférence par e-mail à nathalie.schauner@icold-cigb.org) aussitôt que possible pour être reproduits, afin qu'ils soient remis aux délégués pendant l'Assemblée Générale.

\section{8.- LIBELLÉ DÉFINITIF DES QUATRES QUESTIONS POUR LE 27 CONGRÈS (Règlt. Int. J, f)}

Après discussion des sous-titres des Questions proposés par le Comité ad hoc, le texte final de chaque Question fera l'objet d'un vote séparé d'approbation à main levée. 
19. - ICOLD AWARDS

19.1.- Honorary Members of ICOLD
19.- DISTINCTIONS CIGB

19.1.- Membres d'Honneur de la CIGB 